\title{
Plant oil supplements reduce methane emissions and improve milk fatty acid composition in dairy cows fed grass silage-based diets without affecting milk yield
}

\author{
A. R. Bayat, ${ }^{* 1}$ I. Tapio, $†$ J. Vilkki,† K. J. Shingfield, ${ }^{* 2}$ and H. Leskinen ${ }^{*}$ \\ *Milk Production Solutions, and \\ †Animal Genomics, Green Technology, Natural Resources Institute Finland (Luke), FI-31600 Jokioinen, Finland
}

\begin{abstract}
Four lipid supplements varying in chain length or degree of unsaturation were examined for their effects on milk yield and composition, ruminal $\mathrm{CH}_{4}$ emissions, rumen fermentation, nutrient utilization, and microbial ecology in lactating dairy cows. Five Nordic Red cows fitted with rumen cannulas were used in a $5 \times 5$ Latin square with five $28-\mathrm{d}$ periods. Treatments comprised total mixed rations based on grass silage with a forageto-concentrate ratio of 60:40 supplemented with no lipid (CO) or $50 \mathrm{~g} / \mathrm{kg}$ of diet dry matter (DM) of myristic acid (MA), rapeseed oil (RO), safflower oil (SO), or linseed oil (LO). Feeding MA resulted in the lowest DM intake, and feeding RO reduced DM intake compared with CO. Feeding MA reduced the yields of milk, milk constituents, and energy-corrected milk. Plant oils did not influence yields of milk and milk constituents, but reduced milk protein content compared with $\mathrm{CO}$. Treatments had no effect on rumen fermentation characteristics, other than an increase in ammonia- $\mathrm{N}$ concentration due to feeding MA, RO, and SO compared with $\mathrm{CO}$. Lipid supplements reduced daily ruminal $\mathrm{CH}_{4}$ emission; however, the response was to some extent a result of lower feed intake. Lipids modified microbial community structure without affecting total counts of bacteria, archaea, and ciliate protozoa. Dietary treatments had no effect on the apparent total tract digestibility of organic matter, fiber, and gross energy. Treatments did not affect either energy secreted in milk as a proportion of energy intake or efficiency of dietary $\mathrm{N}$ utilization. All lipids lowered de novo fatty acid synthesis in the mammary gland. Plant oils increased proportions of milk fat 18:0, cis 18:1, trans and monounsaturated fatty acids, and decreased saturated fatty
\end{abstract}

Received July 21, 2017.

Accepted October 13, 2017.

${ }^{1}$ Corresponding author: alireza.bayat@luke.fi

${ }^{2}$ Deceased September 11, 2016. acids compared with $\mathrm{CO}$ and MA. Both SO and LO increased the proportion of total polyunsaturated fatty acids, total conjugated linolenic acid, and cis-9,trans-11 conjugated linoleic acid. Feeding MA clearly increased the $\Delta^{9}$ desaturation of fatty acids. Our results provide compelling evidence that plant oils supplemented to a grass silage-based diet reduce ruminal $\mathrm{CH}_{4}$ emission and milk saturated fatty acids, and increase the proportion of unsaturated fatty acids and total conjugated linoleic acid while not interfering with digestibility, rumen fermentation, rumen microbial quantities, or milk production.

Key words: lipids, methane, milk fatty acids, microbial diversity

\section{INTRODUCTION}

It is anticipated that global demand for animal-derived food will increase in the coming decades, mainly due to population growth and income rise in developing countries (Bodirsky et al., 2015). Ruminants contribute to high-quality food production by utilizing inedible plant resources, such as forages and agricultural byproducts. The livestock sector also contributes to rural development, the rural economy, and maintenance of ecosystems, among many other benefits. However, the livestock sector also plays an important role in climate change, contributing $14.5 \%$ of anthropogenic greenhouse gas (GHG) emissions (estimated 7.1 Gt of $\mathrm{CO}_{2}$ equivalents per year; Gerber et al., 2013). Several nutritional and management strategies have been reported to be effective in mitigation of GHG emissions from animal production systems (Knapp et al., 2014). Practical supplementation levels of plant oil and oilseeds $(<80 \mathrm{~g} / \mathrm{kg}$ of total lipid in diet) can lower GHG consistently over time without compromising the performance of growing or lactating cattle; however, at higher levels, feed intake is compromised (Grainger and Beauchemin, 2011).

Lipid supplements have been used to increase diet energy density of lactating dairy cows to meet the high 
energy requirements during early and mid lactation. Dietary lipid supplements are also arguably one of the effective means to lower ruminal $\mathrm{CH}_{4}$ emissions in ruminants (Martin et al., 2010). Dietary supplements of medium-chain SFA (e.g., lauric and myristic acids) have shown potential to reduce $\mathrm{CH}_{4}$ emissions in dairy cows (Odongo et al., 2007; Hollmann et al., 2012). Dietary supplements of plant oils rich in MUFA or PUFA have been shown to reduce $\mathrm{CH}_{4}$ emissions in growing cattle (Beauchemin and McGinn, 2006) and lactating cows (Martin et al., 2010); however, it is crucial to avoid reducing feed intake due to dietary lipid supplementation. One or more mechanisms are thought to contribute to the decrease in $\mathrm{CH}_{4}$ production to dietary lipid supplements, including lowered digestion of $\mathrm{OM}$ in the rumen, shifting rumen fermentation from acetate toward propionate production, and direct inhibitory effects on methanogens and protozoa (Martin et al., 2010). Lower feed intake and replacement of fermentable OM by lipids also contributes to lower $\mathrm{CH}_{4}$ production (Knapp et al., 2014). However, changes in the rumen microbial community associated with decreased ruminal $\mathrm{CH}_{4}$ production to lipid supplements are not well characterized. Recent advances in sequencing methodology have made it possible to use $16 \mathrm{~S}$ to $18 \mathrm{~S}$ rRNA gene sequences to describe microbial communities under normal rumen conditions (Henderson et al., 2015).

Milk and dairy products are a major source of SFA in the human diet, but serve also as a versatile source of nutrients (Kliem and Shingfield, 2016). Altering the fatty acid composition of milk offers an opportunity to lower consumption of SFA without losing the benefits of other nutrients and bioactive lipids present in milk. Interest exists in manipulating milk fatty acid composition by reducing SFA and increasing UFA or CLA through dairy cow nutrition, especially dietary lipid supplementation (Dewhurst et al., 2006), as well as decreasing the ratio of omega-6 to omega-3 fatty acids (Welter et al., 2016). Both type and source of lipid supplement together with the composition of the basal diet can affect the composition of these fatty acids in milk (Dewhurst et al., 2006). Although inclusion of medium-chain SFA in the diet elevates their contents in milk (Jordan et al., 2006; Machmüller, 2006; Hristov et al., 2009), they are considered unhealthy for humans; thus, dietary plant oil and oilseed supplements can improve milk fatty acid composition to meet the consumers' demand (Dewhurst et al., 2006; Welter 2016).

The aim of the current experiment was to evaluate suitability of dietary lipid supplementation as a $\mathrm{CH}_{4^{-}}$ mitigation strategy that can simultaneously improve milk fatty acid composition using diets based on restrictively fermented grass silage. The study examined the effects of dietary supplements of a medium-chain fatty acid (myristic acid) or long-chain UFA sources rich in cis-9 18:1, 18:2n-6, and 18:3n-3 (rapeseed, safflower, and linseed oil, respectively) on intake, milk production and composition, milk fatty acid composition, nutrient digestion, ruminal $\mathrm{CH}_{4}$ emissions, and microbial ecology.

\section{MATERIALS AND METHODS}

\section{Animals, Experimental Design, and Diets}

National Ethics Committee (ESAVI/576/04.10.03/ 2012, Hämeenlinna, Finland) approved all experimental procedures in accordance with the guidelines established by the European Community Council Directives 86/609/EEC (European Union, 1986). Five multiparous Nordic Red dairy cows in early lactation fitted with rumen cannula (\#1C, i.d. 100 mm; Bar Diamond Inc., Parma, ID) of $63 \pm 5.2$ DIM (mean \pm SE), $705 \pm 11.4$ $\mathrm{kg} \mathrm{BW}, 4.0 \pm 0.3$ parity, and producing $35.2 \pm 1.3 \mathrm{~kg}$ of milk/d were used in a $5 \times 5$ Latin square with 28 -d experimental periods comprising $15 \mathrm{~d}$ of adaptation, 8 $\mathrm{d}$ of sampling, and $5 \mathrm{~d}$ of washout in each experimental period to minimize treatment carryover effects.

Cows were housed in individual tiestalls, had free access to water and salt block, and were milked twice daily at 0700 and $1645 \mathrm{~h}$. Treatments comprised a basal diet (CO), or the basal diet supplemented with $50 \mathrm{~g} / \mathrm{kg}$ of diet DM of methyl esters of myristic acid (MA; SigmaAldrich, St. Louis, MO), rapeseed oil (RO; Raisioagro Ltd., Raisio, Finland), safflower oil (SO; Statfold Seed Oil Ltd., Staffordshire, UK), or linseed oil (LO; Elixi Oil Ltd., Somero, Finland). Lipid supplements replaced barley grain and molassed sugar beet pulp and were introduced to the diet gradually over the first $3 \mathrm{~d}$ of each period. The level of lipid supplementation $(50 \mathrm{~g} /$ $\mathrm{kg}$ of DM) was chosen to benefit from maximum effects on milk fatty acids and enteric $\mathrm{CH}_{4}$ without compromising the DMI of the cows. Diets were fed as 5 equal meals at 0600, 0900, 1200, 1630, and $1930 \mathrm{~h}$. The basal diet was a TMR with a 60:40 forage-to-concentrate ratio on a DM basis (Table 1 ). Diets were formulated to be isonitrogenous and fed as TMR to avoid selection of dietary components and to maintain the desired forage-to-concentrate ratio. The forage was a mixture of 2 grass silages grown at Jokioinen $\left(60^{\circ} 49^{\prime} \mathrm{N}, 23^{\circ} 28^{\prime} \mathrm{E}\right)$, prepared from first and second cut (50:50 on a DM basis, respectively) of timothy and meadow fescue (54:46), and ensiled with a formic acid-based ensiling additive (AIV2 plus, 5 L/t; AIV Valio Ltd., Helsinki, Finland). Experimental diets were offered ad libitum to result in $5 \%$ refusals and the control diet was formulated to meet 
or exceed ME and MP requirements for $35 \mathrm{~kg}$ of milk (MTT Agrifood Research Finland, 2006).

\section{Measurements and Chemical Analysis}

Daily feed intake and milk yield were recorded throughout the experiment, but only measurements made between d 19 and 23 were used for statistical analysis. During this period, representative samples of silage and concentrates were collected daily, composited, and submitted for chemical composition determinations (Shingfield et al., 2002). Concentrations of gross energy (GE) in samples of silage, concentrates, lipid supplements, and excreta were determined by bomb calorimetry (1108 Oxygen bomb, Parr Instrument, Moline, IL). Indigestible NDF of silage, concentrate, and feces was determined by $12 \mathrm{~d}$ of ruminal incubation using nylon bags $(60 \times 120 \mathrm{~mm}$, pore size $0.017 \mathrm{~mm})$ followed by NDF analysis. Samples of rumen fluid (n
$=8$ ) were collected on d 23 of each period from each cow at 1.5-h intervals from 0600 until $1630 \mathrm{~h}$. Following removal, $\mathrm{pH}$ was measured and samples were filtered through 2 layers of cheesecloth. Samples of rumen fluid were stored at $-20^{\circ} \mathrm{C}$ until analyzed for VFA and ammonia- $\mathrm{N}$ determinations by procedures described in Shingfield et al. (2002).

Ruminal $\mathrm{CH}_{4}$ emission was measured between d 16 and 22 of each period using the sulfur hexafluoride $\left(\mathrm{SF}_{6}\right)$ tracer technique (Boadi et al., 2002) with modifications. Sampling details and sample analysis are described by Bayat et al. (2015). Total-tract apparent digestibility coefficients were determined by total fecal collection over a 96-h interval starting at $1800 \mathrm{~h}$ on d 19 of each experimental period. Excreted feces were weighed, thoroughly mixed, subsampled (5\%, wt/wt), and stored at $-20^{\circ} \mathrm{C}$ before chemical analysis. Urine was separated from feces by means of a lightweight harness and flexible tubing attached to the vulva, and

Table 1. Formulation and chemical composition of experimental TMR

\begin{tabular}{|c|c|c|c|c|c|}
\hline \multirow{2}{*}{$\begin{array}{l}\text { Item }(\mathrm{g} / \mathrm{kg} \text { of } \mathrm{DM} \text {, } \\
\text { unless otherwise stated })\end{array}$} & \multicolumn{5}{|c|}{ Treatment $^{1}$} \\
\hline & $\mathrm{CO}$ & MA & RO & $\mathrm{SO}$ & $\mathrm{LO}$ \\
\hline \multicolumn{6}{|l|}{ Inclusion rate } \\
\hline Grass silage $^{2}$ & 600 & 597.2 & 597.2 & 597.2 & 597.2 \\
\hline Barley grain & 180 & 147 & 147 & 147 & 147 \\
\hline Molassed sugar beet pulp & 90 & 73 & 73 & 73 & 73 \\
\hline Rapeseed meal $^{3}$ & 115 & 115 & 115 & 115 & 115 \\
\hline Urea & - & 2.8 & 2.8 & 2.8 & 2.8 \\
\hline Myristic acid ${ }^{4}$ & - & 50 & - & - & - \\
\hline Rapeseed oil & - & - & 50 & - & - \\
\hline Safflower oil & - & - & - & 50 & - \\
\hline Linseed oil & - & - & - & - & 50 \\
\hline Vitamins and minerals ${ }^{5}$ & 15 & 15 & 15 & 15 & 15 \\
\hline \multicolumn{6}{|l|}{ Chemical composition $^{6}$} \\
\hline $\mathrm{DM}$ & 493 & 498 & 498 & 498 & 498 \\
\hline $\mathrm{OM}$ & 913 & 913 & 913 & 913 & 913 \\
\hline $\mathrm{CP}$ & 164 & 165 & 165 & 165 & 165 \\
\hline $\mathrm{EE}$ & 36.5 & 85.0 & 85.0 & 85.3 & 85.1 \\
\hline NDF & 394 & 378 & 378 & 378 & 378 \\
\hline pdNDF & 321 & 309 & 309 & 309 & 309 \\
\hline $\mathrm{ADF}$ & 224 & 217 & 217 & 217 & 217 \\
\hline WSC & 33.9 & 32.1 & 32.1 & 32.1 & 32.1 \\
\hline Starch & 106 & 90.6 & 90.6 & 90.6 & 90.6 \\
\hline Gross energy $(\mathrm{MJ} / \mathrm{kg}$ of $\mathrm{DM})$ & 17.7 & 18.8 & 18.8 & 18.8 & 18.9 \\
\hline \multicolumn{6}{|c|}{$\begin{array}{l}{ }^{1} \text { Refers to grass silage-based diets containing no supplemental lipid (CO) or } 50 \mathrm{~g} / \mathrm{kg} \text { of DM of myristic acid } \\
\text { (MA), rapeseed oil (RO), safflower oil (SO), and linseed oil (LO). }\end{array}$} \\
\hline \multicolumn{6}{|c|}{$\begin{array}{l}{ }^{2} \text { Mean fermentation characteristics of experimental silage: } \mathrm{pH}, 4.09 ; \text { in } \mathrm{DM}(\mathrm{g} / \mathrm{kg}) \text { lactic acid, } 65.4 \text {; acetic acid, } \\
\text { 18.0; propionic acid, } 0.25 \text {; butyric acid, } 1.03 \text {; soluble } \mathrm{N}(\mathrm{g} / \mathrm{kg} \text { of total } \mathrm{N}), 597 ; \text { ammonium } \mathrm{N}(\mathrm{g} / \mathrm{kg} \text { of total } \mathrm{N}) \text {, } \\
\text { 71.7; gross energy }(\mathrm{MJ} / \mathrm{kg} \text { of } \mathrm{DM}), 18.76 \text {. }\end{array}$} \\
\hline \multicolumn{6}{|c|}{${ }^{3}$ Solvent extracted of low glucosinolate content. } \\
\hline \multicolumn{6}{|c|}{$\begin{array}{l}{ }^{4} \text { Gross energy content } 40.3,41.4,41.3 \text {, and } 41.7 \mathrm{MJ} / \mathrm{kg} \text { of DM for myristic acid, rapeseed oil, safflower oil, and } \\
\text { linseed oil, respectively. }\end{array}$} \\
\hline \multicolumn{6}{|c|}{$\begin{array}{l}{ }^{5} \text { Proprietary vitamin and mineral supplement }(3 \text {, Onni-Kivennäinen, Melica Finland Ltd., Vaasa, Finland) de- } \\
\text { clared as containing: }(\mathrm{g} / \mathrm{kg}) \text { calcium, 205; magnesium, } 72 ; \text { sodium, } 85 \text {; phosphorus, } 27 \text {; zinc, } 1.46 \text {; manganese } \\
0.35 \text {; copper, } 0.27 ;(\mathrm{mg} / \mathrm{kg}) \text { iodine, } 39 ; \text { cobalt, } 27 \text {; selenium, } 20 ;(\mathrm{IU} / \mathrm{g}) \text { retinyl acetate, } 120 ; \text { cholecalciferol, } 25 \\
\text { and DL- } \alpha \text { tocopheryl acetate, } 0.34 \text {. }\end{array}$} \\
\hline
\end{tabular}


collected in plastic canisters containing $500 \mathrm{~mL}$ of $5 \mathrm{M}$ sulfuric acid. Collection vessels were changed at 12 -h intervals and daily samples (5\%, wt/wt) were taken and stored at $-20^{\circ} \mathrm{C}$.

Samples of milk were collected over 6 consecutive milkings starting at $1700 \mathrm{~h}$ on d 20. Milk samples treated with preservative (Bronopol, Valio Ltd.) were pooled according to milk yield and analyzed for milk fat, CP, and lactose by infrared analysis (MilkoScan 133B, Foss Electric, Hillerød, Denmark). Milk samples without preservative were also collected on d 22 afternoon milking and on d 23 morning milking and stored at $-20^{\circ} \mathrm{C}$ for milk fatty acid analysis.

\section{Lipid Analysis}

Fatty acid methyl esters of lipid in feed and milk samples were prepared according to standard laboratory methods (Shingfield et al., 2003). Total FAME profile was determined by using a gas chromatograph $(6890 \mathrm{~N}$, Agilent Technologies, Santa Clara, CA) equipped with a CP-Sil 88 column $(100 \mathrm{~m} \times 0.25 \mathrm{~mm}$ i.d., $0.2 \mu \mathrm{m}$ film thickness, Agilent Technologies) and flame ionization detector with a temperature gradient program (Shingfield et al., 2003) and a pressure program (Leskinen et al., 2016). Identification was based on retention time comparisons with authentic FAME standards (Larodan Fine Chemicals AB, Malmö, Sweden; Nu-Chek Prep Inc., Elysian, MN; Sigma-Aldrich) and verified by GCMS (6890 and 5973, Agilent Technologies) in positive electron ionization mode for FAME and corresponding 4,4-dimethyloxazoline derivatives (Shingfield et al., 2003). Distribution of CLA isomers in milk was determined by silver ion HPLC using 4 ChromSpher 5 Lipids columns $(250 \times 4.6 \mathrm{~mm}$ i.d., $5 \mu \mathrm{m}$ particle size, Agilent Technologies) in series without recycling of fractions (Shingfield et al., 2003).

\section{Microbial Analysis}

Digesta samples for microbial analysis were collected from 4 sites (anterior dorsal, anterior ventral, posterior dorsal, and posterior ventral) within the rumenreticulum at $1500 \mathrm{~h}$ on d 20 and $0900 \mathrm{~h}$ on d 22 of each period. Immediately after collection, digesta was squeezed through 2 layers of cheesecloth, and $500 \mu \mathrm{L}$ of rumen liquid were mixed with $1.0 \mathrm{~mL}$ of PBS-glycerol $(30 \% \mathrm{vol} / \mathrm{vol})$ buffer and frozen at $-80^{\circ} \mathrm{C}$. Total genomic DNA was extracted from $1.0 \mathrm{~mL}$ of mixed d 20 and 22 samples following the protocol described by $\mathrm{Yu}$ and Morrison (2004). The PCR amplification of bacterial and archaeal 16S rRNA genes using universal primers, protozoal 18S rRNA genes and fungal ITS1 region, sequencing procedure, and sequence data analysis were described in Tapio et al. (2016).

\section{Calculations}

Total-tract digestibility coefficients of nutrients were calculated based on the difference of intake and fecal excretion. Daily ME intake was calculated as the difference between GE intake and energy excretions as feces, urine, and $\mathrm{CH}_{4}$. Energy of $\mathrm{CH}_{4}$ was calculated using the conversion factor $55.24 \mathrm{~kJ} / \mathrm{g}$ (Kriss, 1930). Energy-corrected milk and energy secretion in milk were calculated based on the yields of fat, $\mathrm{CP}$, and lactose, as $\mathrm{ECM}=$ milk $(\mathrm{kg} / \mathrm{d}) \times[38.3 \times$ fat $(\mathrm{g} / \mathrm{kg})$ $+24.2 \times$ protein $(\mathrm{g} / \mathrm{kg})+16.54 \times$ lactose $(\mathrm{g} / \mathrm{kg})+$ 20.7]/3,140 (Sjaunja et al., 1990). Nitrogen balance was calculated as the difference between $\mathrm{N}$ intake and $\mathrm{N}$ excretion in feces, urine, and milk.

\section{Statistical Analysis}

Experimental data were analyzed by ANOVA for a 5 $\times 5$ Latin square using the GLIMMIX procedure of SAS (version 9.4, SAS institute, Cary, NC) with a model that included fixed effects of period and treatment, and random effect of cow assuming an autoregressive orderone covariance structure fitted on the basis of Akaike information and Schwarz Bayesian model-fit criteria. Least squares means \pm standard error of means are reported and treatment effects declared significant at $P \leq 0.05$, whereas a tendency or trend was assumed for $0.05<P<0.10$. When the overall effect of treatment was significant, pairwise differences among means were explored further using Tukey's test. A multivariate method was used to explore treatment effects on changes in bacterial, archaeal, ciliate protozoal, and fungal population composition. Between-sample diversity was evaluated as Bray-Curtis dissimilarities following Hellinger transformation and visualized using nonmetric multidimensional scaling as an ordination technique. Distance-based permutational multivariate ANOVA (adonis) was used to assess significant differences with respect to diet. Significance was defined at $P<0.05$ after 999 permutations, as implemented in $\mathrm{R}$ package vegan (Oksanen et al., 2013). Treatment effects on individual microbial taxa were evaluated by ANOVA as described above. Before the test, number of reads were $\log$ base transformed $\left[\log _{2}(\mathrm{x}+1)\right]$ and standardized by data centering. Data normality was tested using the Shapiro-Wilk test in SAS. For easier interpretation of results, number of reads of microbial taxa, identified as significantly affected by treatment in ANOVA analysis, were converted to compositional data 
and presented as relative percent abundances within each microbial category.

\section{RESULTS}

\section{Intake, Milk Production, and Milk Composition}

Feeding MA resulted in the lowest $(P<0.01)$ intakes of DM and nutrients compared with all other treatments, and feeding RO reduced $(P<0.01) \mathrm{DM}$, OM, and $\mathrm{CP}$ intakes compared with CO (Table 2). Intakes of other components, except ether extract, were lower $(P$ $<0.01)$ for all plant oil treatments compared with $\mathrm{CO}$. Intakes of DM and all nutrients were similar $(P \geq 0.30)$ among the plant oil treatments. Intake of ether extract was the lowest $(P<0.01)$ with $\mathrm{CO}$, increased with MA, and increased further with plant oils.

Feeding dietary supplement of MA reduced $(P<$ 0.01 ) yields of milk, milk constituents, and ECM in addition to milk protein and lactose contents compared with all other treatments (Table 3). Compared with $\mathrm{CO}$, feeding MA increased $(P<0.01)$ milk fat content. Milk yield and composition were not $(P \geq 0.12)$ different among plant oils and $\mathrm{CO}$ with the exception of milk protein content, which was lower $(P \leq 0.03)$ for plant oils compared with CO.

\section{Rumen Fermentation and Ruminal Gas Emissions}

Treatments had no effect $(P>0.05)$ on rumen $\mathrm{pH}$ or rumen fermentation characteristics, other than an increase $(P \leq 0.04)$ in ammonia- $\mathrm{N}$ concentration due to feeding MA, RO, and SO compared with $\mathrm{CO}$ and feeding MA compared with LO (Table 4). Lipid supplements reduced $(P \leq 0.02)$ daily ruminal $\mathrm{CH}_{4}$ emission and tended $(P=0.08)$ to reduce daily $\mathrm{CH}_{4}$ emission expressed as a function of OM intake, but had no effect $(P \geq 0.12)$ when daily $\mathrm{CH}_{4}$ emission was expressed as a function of total-tract apparent $\mathrm{OM}$ digestion (Table $5)$. Feeding $\mathrm{RO}, \mathrm{SO}$, and $\mathrm{LO}$ reduced $(P<0.05) \mathrm{CH}_{4}$

Table 2. Effect of dietary lipid supplements on nutrient intake of lactating cows fed grass silage-based diets

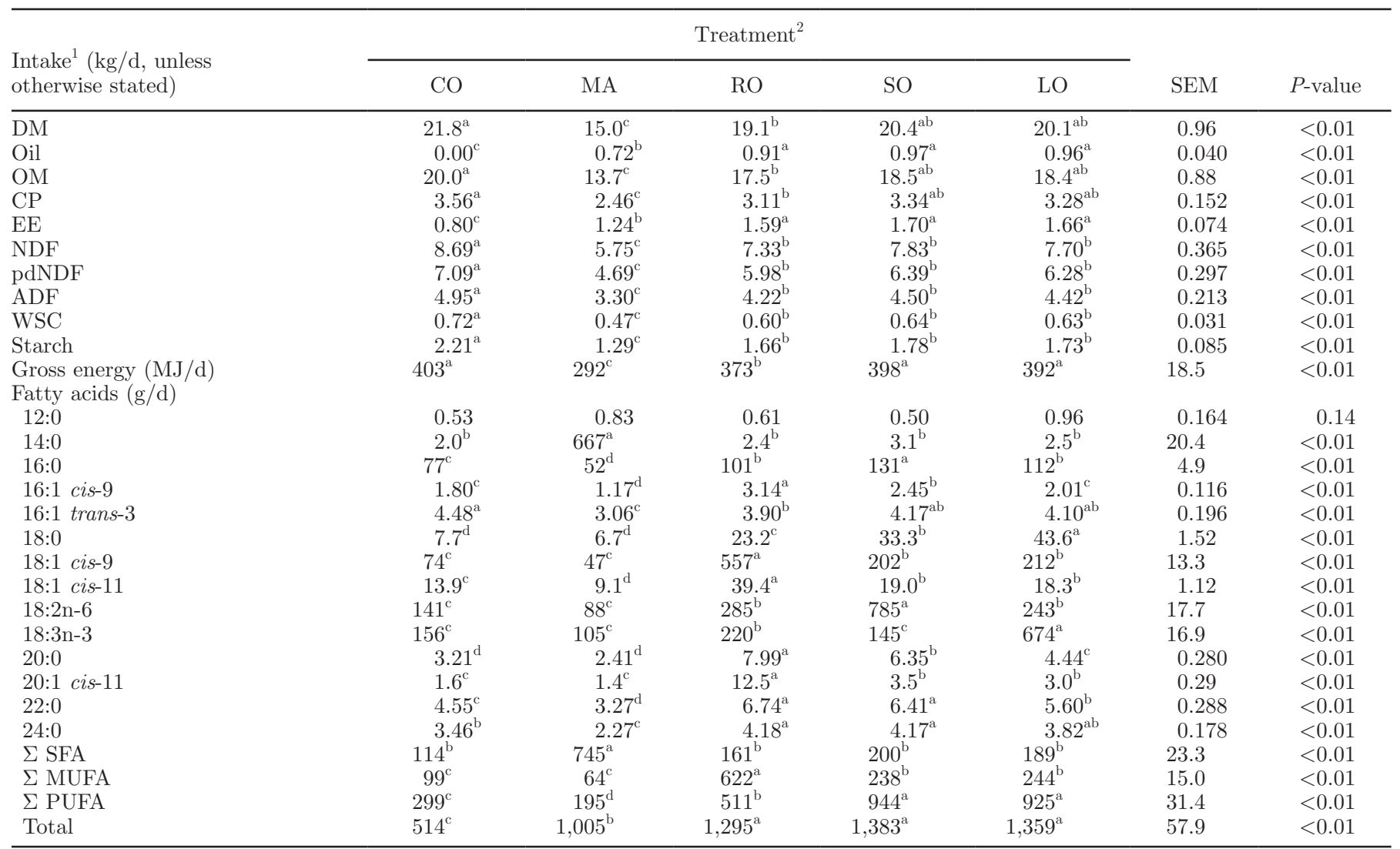

${ }^{\mathrm{a}-\mathrm{d}}$ Within a row, means without a common superscript differ $(P<0.05)$.

${ }^{1} \mathrm{EE}=$ ether extract; pdNDF $=$ potentially digestible NDF; WSC $=$ water-soluble carbohydrates.

${ }^{2}$ Refers to grass silage-based diets containing no supplemental lipid (CO) or $50 \mathrm{~g} / \mathrm{kg}$ of DM of myristic acid (MA), rapeseed oil (RO), safflower oil (SO), and linseed oil (LO). Values are LSM and pooled SEM for $\mathrm{n}=5$. 
Table 3. Effect of dietary lipid supplements on milk yield and milk composition of lactating cows fed grass silage-based diets

\begin{tabular}{|c|c|c|c|c|c|c|c|}
\hline Item & \multicolumn{5}{|c|}{ Treatment $^{1}$} & SEM & $P$-value \\
\hline \multicolumn{8}{|l|}{ Yield } \\
\hline $\mathrm{ECM}^{2}(\mathrm{~kg} / \mathrm{d})$ & $28.3^{\mathrm{a}}$ & $22.7^{\mathrm{b}}$ & $29.1^{\mathrm{a}}$ & $28.9^{\mathrm{a}}$ & $29.1^{\mathrm{a}}$ & 2.68 & $<0.01$ \\
\hline Fat $(\mathrm{g} / \mathrm{d})$ & $1,131^{\mathrm{ab}}$ & $1.014^{\mathrm{b}}$ & $1.213^{\mathrm{a}}$ & $1,162^{\mathrm{ab}}$ & $1,213^{\mathrm{a}}$ & 107.8 & $<0.01$ \\
\hline Protein (g/d) & $977^{\mathrm{a}}$ & $682^{\mathrm{b}}$ & $949^{\mathrm{a}}$ & $976^{\mathrm{a}}$ & $950^{\mathrm{a}}$ & 87.3 & $<0.01$ \\
\hline \multicolumn{8}{|c|}{ Concentration $(\mathrm{g} / \mathrm{kg})$} \\
\hline Fat & $39.2^{\mathrm{b}}$ & $46.7^{\mathrm{a}}$ & $41.8^{\mathrm{b}}$ & $39.3^{\mathrm{b}}$ & $42.8^{\mathrm{ab}}$ & 1.29 & $<0.01$ \\
\hline Protein & $34.3^{\mathrm{a}}$ & $31.1^{\mathrm{c}}$ & $33.1^{\mathrm{b}}$ & $33.1^{\mathrm{b}}$ & $33.4^{\mathrm{b}}$ & 0.64 & $<0.01$ \\
\hline Lactose & $45.1^{\mathrm{a}}$ & $41.7^{\mathrm{b}}$ & $44.2^{\mathrm{a}}$ & $44.8^{\mathrm{a}}$ & $45.0^{\mathrm{a}}$ & 0.68 & $<0.01$ \\
\hline
\end{tabular}

${ }^{\mathrm{a}-\mathrm{c}}$ Within a row, means without a common superscript differ $(P<0.05)$.

${ }^{1}$ Refers to grass silage-based diets containing no supplemental lipid (CO) or $50 \mathrm{~g} / \mathrm{kg}$ of DM of myristic acid (MA), rapeseed oil (RO), safflower oil (SO), and linseed oil (LO). Values are LSM and pooled SEM for $\mathrm{n}=5$.

${ }^{2}$ Energy-corrected milk yield calculated according to Sjaunja et al. (1990)

emission per kilogram of ECM when compared with $\mathrm{CO}$, whereas SO and LO reduced $(P<0.03)$ and $\mathrm{RO}$ tended $(P=0.07)$ to reduce proportion of energy intake lost as $\mathrm{CH}_{4}$ compared with $\mathrm{CO}$ (Table 5).

\section{Nutrient Utilization}

Dietary treatments had no effect $(P \geq 0.52)$ on OM, fiber, and GE apparent total-tract digestibility (Table $6)$. Feeding MA increased $(P \leq 0.04)$ digestibility of $\mathrm{N}$ compared with $\mathrm{CO}$ and $\mathrm{LO}$, whereas feeding $\mathrm{SO}$ and LO decreased $(P \leq 0.05)$ digestibility of starch compared with CO. Energy secreted in milk as a proportion of GE intake was not affected $(P=0.18)$ by lipid supplements (Table 7). However, feeding MA increased $(P<0.05)$ urinary energy excretion as a proportion of GE intake compared with $\mathrm{CO}$ and SO. Feeding MA increased $(P$ $<0.01)$ the proportion of dietary $\mathrm{N}$ excreted in urine compared with other treatments (Table 7). Feeding RO tended $(P=0.09)$ to increase efficiency of dietary $\mathrm{N}$ utilization, defined as the ratio of milk $\mathrm{N}$ output to $\mathrm{N}$ intake, compared with $\mathrm{CO}$. Nitrogen balance was lower $(P=0.02)$ when MA compared with $\mathrm{CO}$ was fed.

\section{Milk Fatty Acid Composition}

All lipid supplements lowered $(P<0.05)$ relative proportions of several fatty acids, including all 5 - to 12 -carbon fatty acids, 15:0, 16:0, 17:0, 11-cyclohexyl-11:0, 20:3n-6, unresolved 20:5n-3 + 24:0, 22:4n-6, 22:5n-3, 26:0, branched-chain fatty acids up to 16 carbons, and anteiso 17:0; whereas supplements increased $(P<$

Table 4. Effect of dietary lipid supplements on rumen fermentation characteristics of lactating cows fed grass silage-based diets

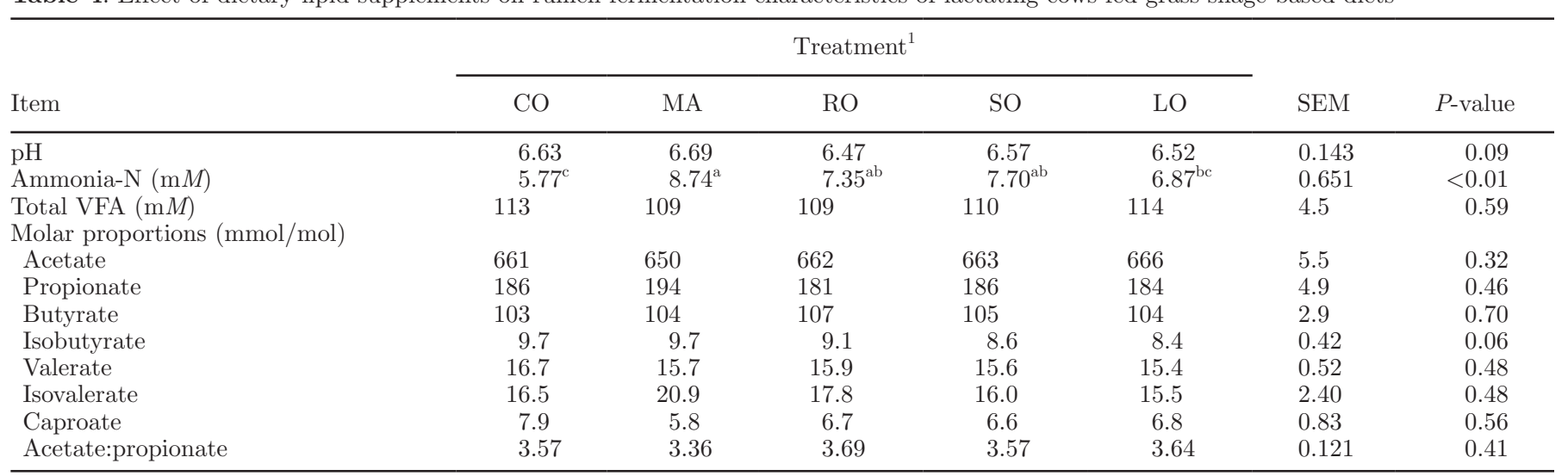

\footnotetext{
${ }^{\mathrm{a}-\mathrm{c}}$ Within a row, means without a common superscript differ $(P<0.05)$.

${ }^{1}$ Refers to grass silage-based diets containing no supplemental lipid (CO) or $50 \mathrm{~g} / \mathrm{kg}$ of DM of myristic acid (MA), rapeseed oil (RO), safflower oil (SO), and linseed oil (LO). Values are LSM and pooled SEM for $\mathrm{n}=5$.
} 
Table 5. Effect of dietary lipid supplements on ruminal methane production of lactating cows fed grass silage-based diets ${ }^{1}$

\begin{tabular}{|c|c|c|c|c|c|c|c|}
\hline Ruminal $\mathrm{CH}_{4}$ & \multicolumn{5}{|c|}{ Treatment $^{2}$} & SEM & $P$-value \\
\hline $\mathrm{g} / \mathrm{d}$ & $614^{\mathrm{a}}$ & $403^{\mathrm{b}}$ & $475^{\mathrm{b}}$ & $488^{\mathrm{b}}$ & $484^{\mathrm{b}}$ & 34.8 & $<0.01$ \\
\hline $\mathrm{g} / \mathrm{kg}$ of $\mathrm{DOM}$ & 42.2 & 40.5 & 37.9 & 36.1 & 36.3 & 2.57 & 0.12 \\
\hline $\mathrm{g} / \mathrm{kg}$ of $\mathrm{ECM}$ & $22.7^{\mathrm{a}}$ & $18.8^{\mathrm{ab}}$ & $17.5^{\mathrm{b}}$ & $17.5^{\mathrm{b}}$ & $17.5^{\mathrm{b}}$ & 2.48 & 0.02 \\
\hline$\%$ of GEI & $8.43^{\mathrm{a}}$ & $7.65^{\mathrm{ab}}$ & $7.08^{\mathrm{ab}}$ & $6.80^{\mathrm{b}}$ & $6.86^{\mathrm{b}}$ & 0.494 & 0.02 \\
\hline
\end{tabular}

${ }_{\mathrm{a}, \mathrm{b}}$ Within a row, means without a common superscript differ $(P<0.05)$.

${ }^{1} \mathrm{OMI}=$ organic matter intake $(\mathrm{kg} / \mathrm{d}) ; \mathrm{DOM}=$ organic matter digested in total digestive tract $(\mathrm{kg} / \mathrm{d}) ; \mathrm{GEI}=$ gross energy intake $(\mathrm{MJ} / \mathrm{d})$.

${ }^{2}$ Refers to grass silage-based diets containing no supplemental lipid (CO) or $50 \mathrm{~g} / \mathrm{kg}$ of DM of myristic acid (MA), rapeseed oil (RO), safflower oil (SO), and linseed oil (LO). Values are LSM and pooled SEM for $\mathrm{n}=5$.

Table 6. Effect of dietary lipid supplements on total-tract apparent nutrient digestibility $(\mathrm{g} / \mathrm{kg})$ of lactating cows fed grass silage-based diets

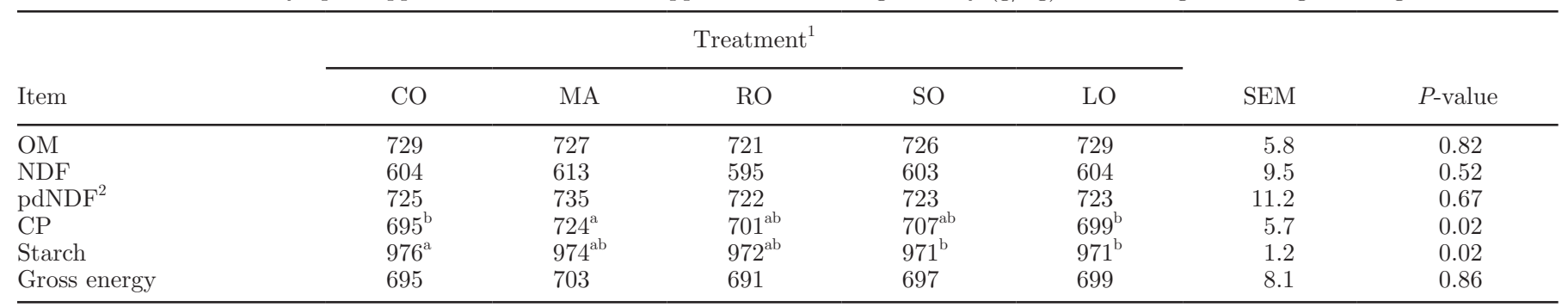

${ }_{\mathrm{a}, \mathrm{b}}$ Within a row, means without a common superscript differ $(P<0.05)$.

${ }^{1}$ Refers to grass silage-based diets containing no supplemental lipid (CO) or $50 \mathrm{~g} / \mathrm{kg}$ of DM of myristic acid (MA), rapeseed oil (RO), safflower oil (SO), and linseed oil (LO). Values are LSM and pooled SEM for $\mathrm{n}=5$.

${ }^{2} \mathrm{pdNDF}=$ potentially digestible NDF.

Table 7. Effect of dietary lipid supplements on energy and nitrogen metabolism of lactating cows fed grass silage-based diets

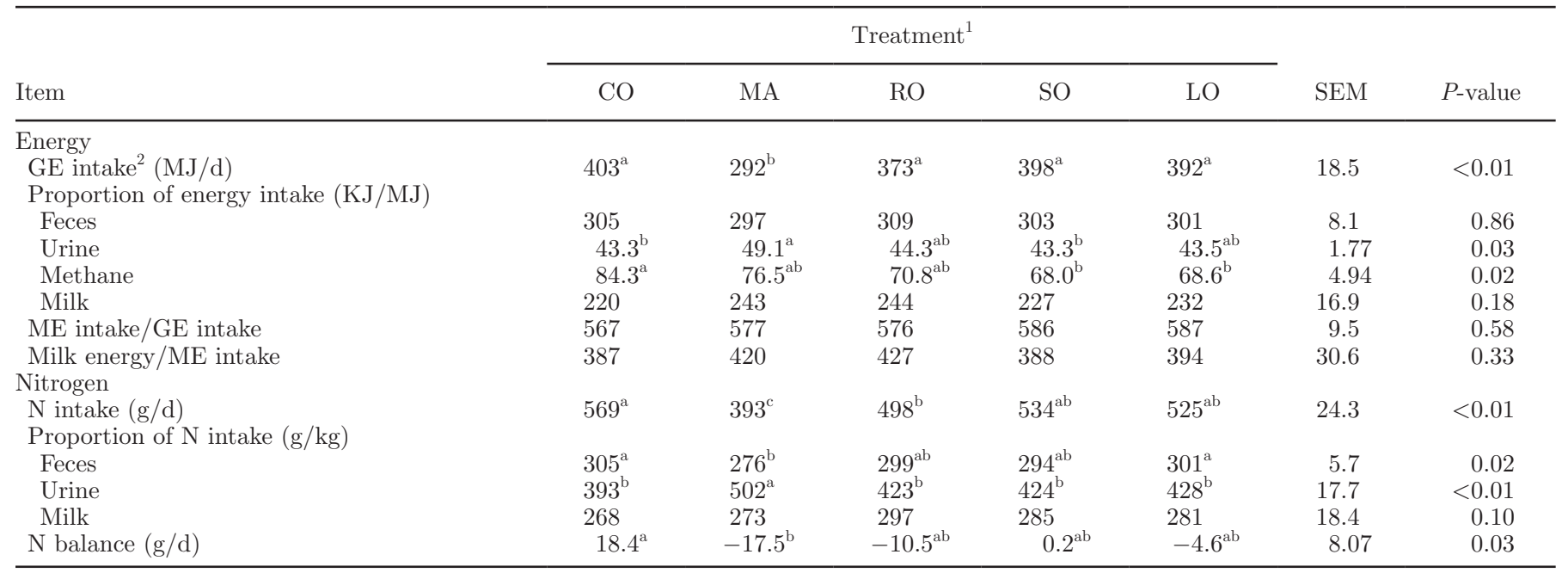

${ }^{\mathrm{a}-\mathrm{c}}$ Within a row, means without a common superscripts differ $(P<0.05)$.

${ }^{1}$ Refers to grass silage-based diets containing no supplemental lipid (CO) or $50 \mathrm{~g} / \mathrm{kg}$ of DM of myristic acid (MA), rapeseed oil (RO), safflower oil (SO), and linseed oil (LO). Values are LSM and pooled SEM for $\mathrm{n}=5$.

${ }^{2} \mathrm{GE}=$ gross energy. 
0.05) cis-7 16:1, cis-13 18:1, and total MUFA (Table 8, Supplemental Tables S1-S4; https://doi.org/10.3168/ jds.2017-13545).

Milk produced by cows fed MA contained the highest $(P<0.05)$ proportions of 14:0, cis-9 14:1, trans-9 $14: 1$, and $\operatorname{cis}(\Delta 9,11) 16: 1$ (Table 8 and Supplemental Table S2; https://doi.org/10.3168/jds.2017-13545). Compared with $\mathrm{CO}$, all plant oils induced changes in milk fatty acid composition, including increases $(P<$ $0.05)$ in proportions of $18: 0$, isomers of $18: 1$, cis, trans $(\Delta 9,13 ; 9,14)$, trans,trans $(\Delta 9,12 ; 9,13 ; 9,14) 18: 2$, trans-7, cis-9 CLA, total trans fatty acids (TFA), total MUFA, and all-cis UFA, as well as decreases $(P$ $<0.05$ ) in 14:0, 16:0, and SFA content (Table 8 and Supplemental Table S3; https://doi.org/10.3168/jds $.2017-13545)$. Both SO and LO increased $(P<0.05)$ proportion of total PUFA compared with other treatments and had the highest $(P<0.05)$ proportion of total TFA (Table 8). Feeding RO resulted in the highest $(P<0.05)$ proportions of trans $(\Delta 4-10) 18: 1$, cis $(\Delta 9$, 13) $18: 1,20: 0$, cis $(\Delta 9,11) 20: 1$, and trans $(\Delta 10-12)$ 20:1 (Supplemental Tables S3 and S4; https://doi.org/ $10.3168 /$ jds.2017-13545). Feeding SO resulted in the highest $(P<0.05)$ proportions of cis $(\Delta 9,12)$ 18:1, trans $(\Delta 9-12)$ 18:1, 18:2n-6, cis-9,trans-11 CLA, trans8,trans-10 CLA, trans-10,trans-12 CLA, and total CLA (Table 8 and Supplemental Table S3). Milk from LO contained the highest $(P<0.05)$ proportions of cis $(\Delta 15,16) 18: 1$, trans $(\Delta 12-16) 18: 1$, cis-9, trans11,cis-15 18:3, cis-9,trans-11,trans-15 18:3, cis-9, trans11,trans-13 18:3, total nonconjugated 18:2, total trans $18: 2$, cis-12,cis-15 18:2, cis,trans $(\Delta 9,13 ; 9,14 ; 10,14)$ $18: 2$, trans, cis $(\Delta 11,15 ; 12,15) 18: 2$, trans,trans $(\Delta 9,12$; 9,14; 11,15) 18:2, trans-13,trans-15 CLA, and all-trans, trans/cis, and cis/trans isomers of $\Delta 11,13$ CLA and $\Delta 12,14$ CLA; milk from LO had the same amount of trans-11,cis-13 CLA as CO (Table 8 and Supplemental Table S3).

Overall, MA resulted in the highest $(P<0.05)$ product/(product + substrate) concentration ratios for stearoyl-CoA desaturase 1, which catalyzes the introduction of a cis double bond at $\Delta^{9}$, with the exception of $12: 1$ cis-9/(12:1 cis-9 + 12:0), whereas CO did not differ from plant oil supplements (Table 8 ).

\section{Rumen Microbial Ecology}

We used 2-dimensional nonmetric multidimensional scaling plots to assess treatment effect on overall rumen microbial community structure (Supplemental Figure S1; https://doi.org/10.3168/jds.2017-13545). Rumen bacteria, archaea, and fungi populations in cows fed MA grouped separately compared with CO or plant oil supplements (adonis test $P<0.01$ ). For ciliate protozoa, no grouping based on treatment was significant.

We further evaluated treatment effects on individual microbial taxa. Lipid supplements had no effect $(P>$ 0.05) on the most common Prevotellaceae and Lachnospiraceae families in bacteria (data not presented). However, MA compared with CO reduced $(P<0.05)$ Fibrobacteraceae, Christensenellaceae, and several less abundant families within Bacteroidetes, TM7, and Tenericutes phyla but increased $(P<0.05)$ abundance of Lactobacillaceae and Veillonellaceae (Firmicutes), Succinivibrionaceae, and other Proteobacteria (Table 9). Compared with $\mathrm{CO}$, feeding LO affected abundance of more bacterial taxa compared with RO or SO. Feeding LO increased abundance of Succinivibrionaceae $(P=0.02)$ and Bacteroidales S24-7 $(P=0.01)$, but decreased abundance of Christensenellaceae $(P=0.04)$ and several low-abundance groups $(P<0.05)$ within Bacteroidetes, Proteobacteria, TM7, and Tenericutes phyla (Table 9).

Within the archaea, MA increased $(P<0.01)$ abundance of Methanosphaera ISO3-F5 and Methanimicrococcus blatticola but decreased $(P<0.01)$ Methanobrevibacter ruminantium and Methanobacterium alcaliphilum. Comparing plant oils with $\mathrm{CO}$, LO had no effect on archaeal abundances whereas with SO the effect was the strongest. Feeding $\mathrm{SO}$ increased $(P=$ 0.03) Methanobacterium alcaliphilum but decreased abundance of Methanosphaera ISO3-F5 $(P=0.01)$ and Methanobrevibacter gottschalkii $(P=0.03$; Table 9$)$.

Among ciliate protozoa, MA reduced $(P<0.05)$ abundance of Isotricha LDK-2011 and Raabena bella, whereas among fungi it diminished $(P<0.01)$ Cecomyces 1 and SK3 but positively affected $(P<0.01)$ abundance of Neocallimastix 1. Fungi KF1 was less abundant $(P=0.01)$ in LO compared with other treatments (Table 9).

\section{DISCUSSION}

The reduction of environmental impact of livestock production and the improvement of the nutritional health aspects of milk would be beneficial to the public and political demand for global food security and will increase the sustainability of dairy production. Nordic feeding conditions are characterized by feeding highforage diets based on grass silage. In the current study, we evaluated dietary lipid supplementation as a tool to reduce enteric $\mathrm{CH}_{4}$ emissions and simultaneously improve milk fatty acid quality. The results of the current study should be interpreted with caution, as the number of cows used in a nonreplicated $5 \times 5$ Latin square might compromise the statistical power of the results obtained. 
Table 8. Effect of dietary lipid supplements on selected fatty acids in milk of lactating cows fed grass silage-based diets

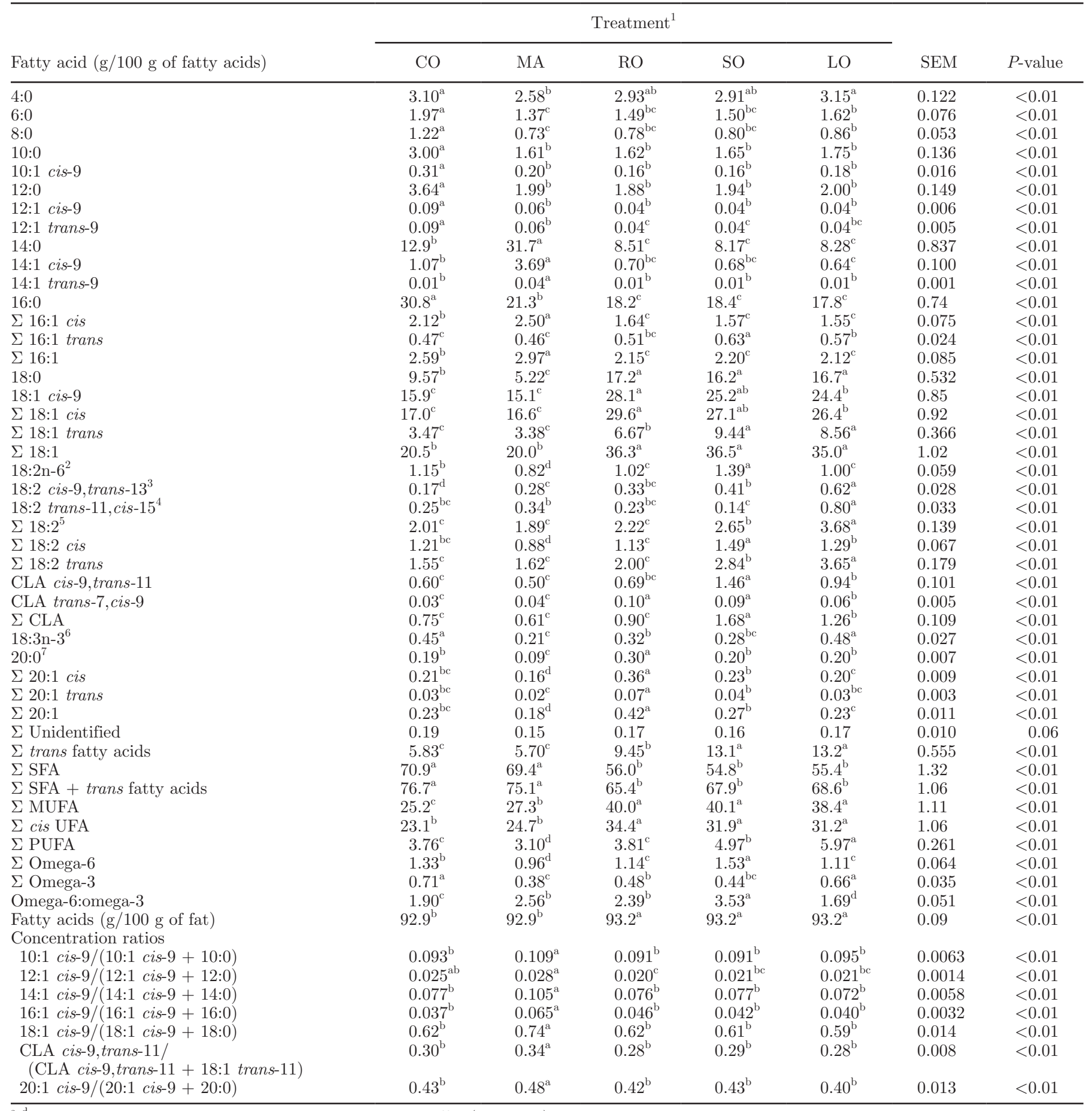

${ }^{\mathrm{a}-\mathrm{d}}$ Within a row, means without a common superscript differ $(P<0.05)$.

${ }^{1}$ Refers to grass silage-based diets containing no supplemental lipid (CO) or $50 \mathrm{~g} / \mathrm{kg}$ of DM of myristic acid (MA), rapeseed oil (RO), safflower oil (SO), and linseed oil (LO). Values are LSM and pooled SEM for $\mathrm{n}=5$.

${ }^{2}$ Co-elutes with cis-9,cis-15 18:2, and cis-9 19:1.

${ }^{3}$ Co-elutes with cis-10,trans-14 18:2.

${ }^{4}$ Co-elutes with trans-10,cis-15 18:2.

${ }^{5}$ Sum of 18:2 fatty acids excluding isomers of CLA.

${ }^{6}$ Co-elutes with trans-15 20:1 and trans-16 20:1.

${ }^{7}$ Co-elutes with an unidentified fatty acid. 
Table 9. Effect of dietary lipid supplements on abundance of rumen microbial populations in lactating cows fed grass silage-based diets

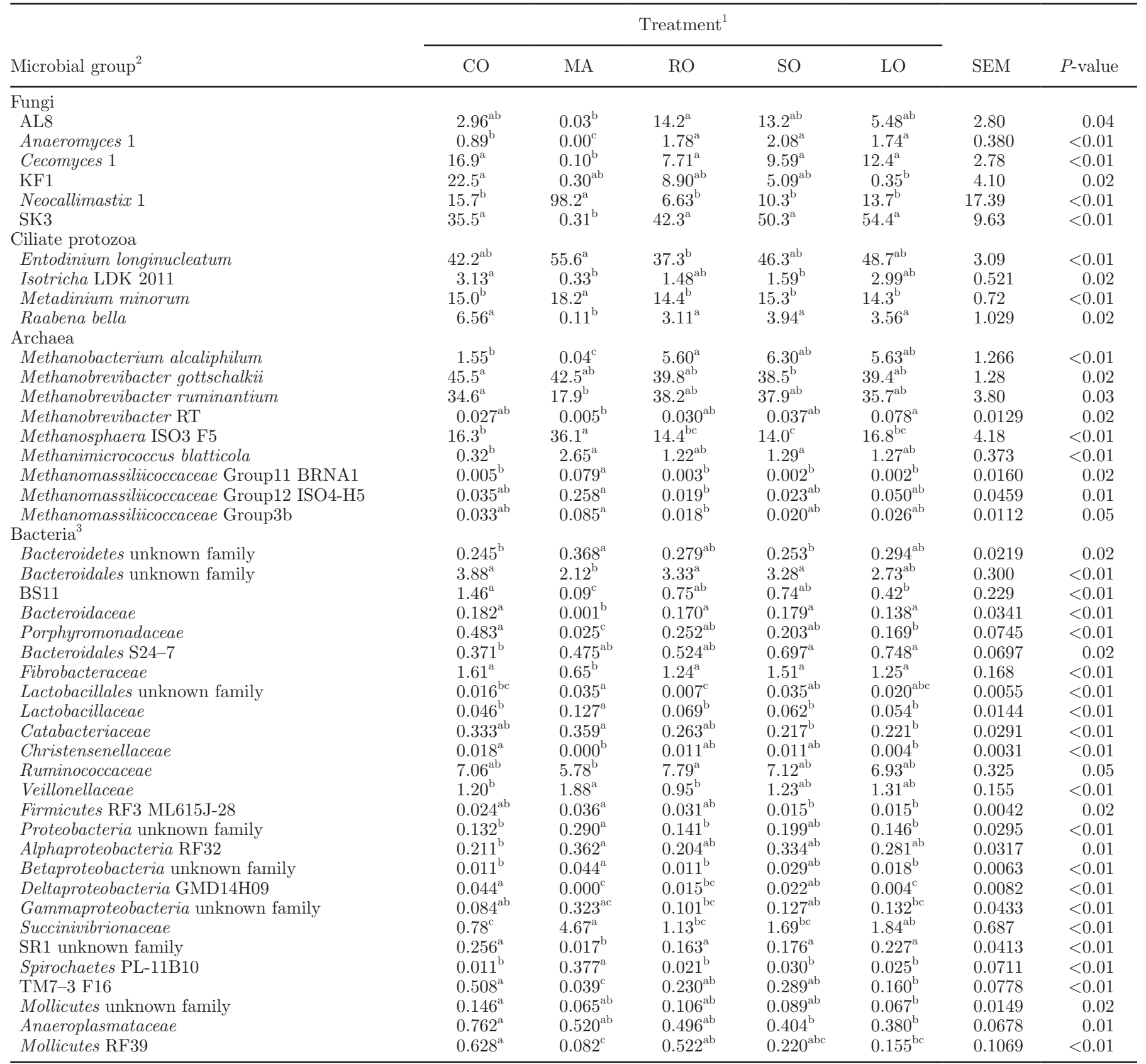

${ }^{\mathrm{a}-c}$ Within a row, means without a common superscript differ $(P<0.05)$.

${ }^{1}$ Refers to grass silage-based diets containing no supplemental lipid (CO) or $50 \mathrm{~g} / \mathrm{kg}$ of DM of myristic acid (MA), rapeseed oil (RO), safflower oil (SO), and linseed oil (LO). Values are LSM and pooled SEM for $\mathrm{n}=5$.

${ }^{2}$ Microbial composition is represented as an average abundance in a percentage for each treatment. Only significant $(P<0.05)$ results are included into the table.

${ }^{3}$ Bacteria are presented at family level; taxa with average abundance per treatment $<1 \%$ are not included.

\section{Intake and Nutrient Digestion}

In the current study, feeding MA was associated with a significant reduction in DMI, whereas plant oils had no effect. This indicated that fatty acid carbon length, rather than the degree of unsaturation, was the factor behind the reduction in DMI. Experiments using myristic acid dietary supplements in dairy cattle are scarce; however, no adverse effect on DMI was reported when cows were fed a TMR containing $50 \mathrm{~g}$ of myris- 
tic acid/kg of DM (Odongo et al., 2007) or when 240 $\mathrm{g}$ of myristic acid per day was mixed manually with rumen contents (Hristov et al., 2011). Differences in response to myristic acid may be related to differences in diet composition and the lower DMI level of cows $(\sim 15 \mathrm{~kg} / \mathrm{d})$ in the study by Odongo et al. (2007) or the low supplemental level $(\sim 9.3 \mathrm{~g} / \mathrm{kg} \mathrm{DM})$ in the study by Hristov et al. (2011). An alternative explanation is that the methyl ester form of myristic acid might have a low palatability to the cows, as supported by our visual observation that cows refused to eat the MA diet. Relatively high levels of dietary plant oil supplements ( $\geq 50 \mathrm{~g}$ of oil $/ \mathrm{kg}$ of DM) are typically associated with lower DMI. This has been attributed to various mechanisms, including the adverse effects of UFA on ruminal microbial communities, lowered ruminal OM and fiber digestion, and a consequent tendency to shift the site of nutrient digestion from rumen to the intestines (Jenkins, 1993), as well as elevated plasma gut peptide concentrations and lower gut motility (Allen, 2000). However, the effect of high levels of plant oils on DMI can be variable, as observed in the present and other studies (Bell et al., 2006; Roy et al., 2006; Shingfield et al., 2008).

None of the lipid supplements varying in chain length or degree of unsaturation tested in the current study influenced $\mathrm{OM}$ and fiber digestibility. Plant oils are known to have inconsistent effects on diet digestibility in lactating cows according to basal diet and supplementation level (Ben Salem et al., 1993; Jenkins, 1998; Chelikani et al., 2004; Shingfield et al., 2008). Benchaar et al. (2015) concluded that linseed oil added to diets of dairy cows at 37 to $55 \mathrm{~g} / \mathrm{kg}$ of DM can lower nutrient digestibility in diets based on cereal forages, but not in diets based on legume or grass forages that differ in starch-to-fiber ratio. This is supported by our results with a diet based on grass silage.

\section{Rumen Fermentation and Ruminal Gas Emissions}

Dietary lipid supplements did not influence rumen fermentation, except ammonia-N. Greater ammonia-N concentration associated with dietary lipid supplementation can be related to the urea used in those diets (Kertz, 2010) to compensate the lower diet CP or lower feed intake. However, low microbial growth and microbial ammonia utilization in the rumen due to lipid supplementation might contribute to higher rumen ammonia- $\mathrm{N}$ concentration, but lack of significant effects of lipid supplementation on total microbial population, as evaluated by quantitative PCR (qPCR) analysis in the complementary study by Tapio et al.
(2016), does not support this speculation. Influence of dietary lipid supplements on molar VFA proportions may depend on composition of the basal diet, inclusion rate, and amount of lipid in the basal diet (Chelikani et al., 2004; Benchaar et al., 2012). Findings of a metaanalysis from experiments with restrictively fermented grass silage, similar to the present experiment, indicate that changes in acetate-to-propionate ratio are rather resistant to concentrate supplementation (Huhtanen et al., 2013). Our results suggest that rumen fermentation pattern with diets based on restrictively fermented grass silage may also be resistant to lipid supplementation, as it did not meet the general expectation that rumen acetate-to-propionate ratio decreases by dietary lipid supplementation (Doreau and Chilliard, 1997).

We measured ruminal $\mathrm{CH}_{4}$ emissions using continuous sampling of rumen gas over 6 consecutive days, rather than analyzing breath samples. If animals fitted with rumen cannulas are used to measure $\mathrm{CH}_{4}$ emission by $\mathrm{SF}_{6}$ tracer technique via breath analysis, $\mathrm{CH}_{4}$ emission may be underestimated compared with noncannulated animals due to the leakage from the cannulas (Beauchemin et al., 2012). Therefore, the cannulated cows used in our study were fitted with custom-made sponges placed between the outer edge of the cannula flange and the abdominal wall to minimize the exchange of ruminal gas with surrounding air.

All the lipid supplements lowered daily $\mathrm{CH}_{4}$ output, which is consistent with earlier reports (Odongo et al., 2007; Martin et al., 2010; Grainger and Beauchemin, 2011). In the current study, lower $\mathrm{CH}_{4}$ output could be partially explained by negative effects of MA and plant oils on intake. Our results contradict earlier observations when $50 \mathrm{~g}$ of myristic acid $/ \mathrm{kg}$ of diet DM was fed to dairy cows (Odongo et al., 2007) and reduced $\mathrm{CH}_{4}$ emission by $36 \%$ with no effect on DMI. Differences between studies can be attributed to differences in level of intake (22 vs. $15 \mathrm{~kg} / \mathrm{d}$ for control diets, respectively) and form of supplement used (methyl ester form of myristic acid vs. myristic acid). Similarly, our findings disagree with those reported by Machmüller et al. (2003), who reported $22 \%$ lower $\mathrm{CH}_{4}$ emission with a high-forage diet in sheep supplemented with $50 \mathrm{~g}$ of myristic acid/ $\mathrm{kg}$ of diet DM without any effect on DMI.

The decrease in $\mathrm{CH}_{4}$ emission due to the plant oils (RO, SO, and LO) compared with CO $(22.6,20.5$, and $21.2 \%$, respectively) could not be explained entirely by decreases in DMI (12.4, 6.4, and 7.8\%, respectively). The dilution effect of oils on diet fermentable $\mathrm{OM}$ and ruminal biohydrogenation of fatty acids as a sink for hydrogen accounted for the rest of effect of plant oils on $\mathrm{CH}_{4}$ emissions (calculations not presented). 


\section{Milk Production and Composition}

The lower yields of milk and milk constituents due to MA were consequences of lower DM and nutrient intakes compared with CO. However, decreases in yields of milk and even ECM were proportionally smaller than the decrease in DMI. The higher milk fat content when MA was fed can be a result of the greater transfer of 14:0 from feed to milk, as indicated by the greater sum of milk C14 fatty acids (about 21\%) compared with the control. The reason for lower milk lactose content when MA was fed is unknown, especially when the treatments did not affect rumen fermentation greatly.

The plant oils used at a relatively high levels did not cause any negative effects on milk yield and yields of milk fat, protein, and lactose compared with $\mathrm{CO}$ despite the lower DMI. The lipid effect on milk yield can be very variable due to source, supplementation level, and lactation stage (Onetti and Grummer, 2004). A meta-analysis (Rabiee et al., 2012) indicated that lipid sources increased milk yield with a tendency to increase milk fat yield without changes in protein yield, even though variation in response was high. It is expected that milk yield increases in response to dietary lipid supplementation after the peak of lactation ( Wu and Huber, 1994), but we did not see such an increase in the current study; this is consistent with some other studies (Bell et al., 2006; Roy et al., 2006; Chilliard et al., 2009; Benchaar et al., 2015). Lack of effect of plant oils on milk fat concentration is not consistent with some studies (Chelikani et al., 2004; Bell et al., 2006), which reported lower milk fat content without alterations in milk yield and other constituents due to high levels of plant oil supplementation. The lack of effect of plant oils on milk fat can be attributed to the lack of changes in rumen fermentation in the diets based on restrictively fermented grass silage. The plant lipids reduced milk protein content, as expected (Doreau and Ferlay, 2015). Glucose deficiency due to substitution of lipids for readily fermentable carbohydrates might decrease rumen microbial protein synthesis and, consequently, AA available at mammary gland for milk protein synthesis (Wu and Huber, 1994). The microbial protein synthesis was not measured in the current study, but the qPCR analysis in the study of Tapio et al. (2016) did not show significant negative lipid effects on total microbial population (as discussed in more details in Rumen Microbial Ecology section).

\section{Milk Fatty Acid Composition}

Dietary plant oils and oilseed supplements have been shown to alter milk fatty acid composition and improve nutritional quality of milk; changes that vary according to composition of the basal diet (Glasser et al., 2008; Dewhurst et al., 2006). Relative to CO, all plant oil supplements consistently decreased 5 - to 17-carbon fatty acid abundance in milk fat; changes that are characteristic in dairy cows fed dietary plant oil supplements (Glasser et al., 2008; Shingfield et al., 2013). In addition, MA decreased these fatty acids, with the exception of an increase in $\mathrm{C} 14$ fatty acids, as was expected based on experiments with 12:0 and 16:0 rich plant oils (Shingfield et al., 2013). Lower proportions of both 16:0 and 18:0 in milk from cows receiving MA compared with the control may result from decreased intake of 16:0 and 18:0 as well as decreased de novo synthesis of 16:0. Higher intake of C18 fatty acids from plant oil supplements increased proportion of $\mathrm{C} 18$ fatty acids in milk. However, the proportion of 16:0 in milk decreased despite higher intake of 16:0 compared with $\mathrm{CO}$. These observations indicate that increased availability of $\mathrm{C} 18$ fatty acids in plant oils and 14:0 in MA suppress de novo synthesis of fatty acids in the mammary gland. The decrease in de novo synthesized 12:0, 14:0, and 16:0 can be considered a favorable change, because consumption of these fatty acids has been shown to increase risk of cardiovascular disease; however, 18:0 is considered a neutral SFA for human health (Kliem and Shingfield, 2016).

Overall, all plant oils decreased the proportion of SFA and increased the proportion of MUFA and TFA in milk fat, confirming earlier results (Rego et al., 2009; Kliem and Shingfield, 2016). Although including plant oils and oilseeds in diets of dairy cows increases the amount of beneficial all-cis UFA in milk, the increase in TFA may have adverse effects on human health. However, the composition pattern of TFA in milk is dependent on the fatty acid composition of lipid supplements, the amount of lipid fed, and the composition of basal diet (Kliem and Shingfield, 2016). In addition, the isomeric distribution of trans MUFA and trans PUFA in ruminant-derived foods and partially hydrogenated industrial vegetable oils are different (Kliem and Shingfield, 2016). Milk fatty acid composition reflected the specific fatty acid compositions of plant oil supplements with characteristic alterations in biohydrogenation intermediates of cis-9 18:1, 18:2n-6, and 18:3n-3 due to incomplete conversion to 18:0. Alterations in the $\mathrm{C} 18$ biohydrogenation intermediates observed in the current experiment were consistent with the pattern reported in recent reviews (Shingfield et al., 2013; Kliem and Shingfield, 2016). High availability of cis-9 18:1 in RO resulted in appearance of biohydrogenation intermediates, including trans-4 to trans-9 18:1 and trans-7,cis-9 CLA, whereas greater intake of $18: 2 \mathrm{n}-6$ 
from SO induced an increased enrichment in trans-9 to trans-12 18:1, cis-12 18:1, cis-9,trans-11 CLA, trans8,trans-10 CLA, and trans-10,trans-12 CLA. Increases in trans-7,cis-9 CLA and cis-9,trans-11 CLA are mostly attributed to the increased availability and $\Delta^{9}$ desaturation of trans-7 18:1 and trans-11 18:1, respectively, in the mammary gland. Consistent with the literature (Glasser et al., 2008; Kliem and Shingfield, 2016), trans 18:1 were the most abundant biohydrogenation intermediates in plant oil treatments in the current study and $\mathrm{RO}$ resulted in a lower increase compared with PUFA-containing SO and LO. Similarly, 18:3n-3 in LO caused appearance of numerous characteristic biohydrogenation intermediates, including cis-15 18:1, cis-16 18:1, trans-12 to trans- 16 18:1, $\Delta 11,13$ CLA, $\Delta 12,14$ CLA, trans-13,trans-15 CLA, $\Delta 9,11,15$ 18:3, and cis9,trans-11,trans-13 18:3. Among all diets, feeding LO resulted in the greatest increase in total nonconjugated 18:2 and total trans 18:2, of which cis-9, trans-13 18:2, and cis-9,trans-14 18:2 can be, at least in part, formed also indirectly via $\Delta^{9}$ desaturation. As an exception, cis-9,trans-11,cis-15 18:3 has been shown to be derived solely from ruminal biohydrogenation (Leskinen et al., 2016). Despite the increase in milk TFA when feeding plant oils, the combined proportion of SFA and TFA decreased compared with CO.

Milk from SO had the highest increase in total CLA, followed by milk from LO, due to the increase in cis-9,trans-11 CLA. However, efficiency of 18:2n-6 enriched oils and linseed oil to increase total CLA and cis-9,trans-11 CLA varies between experiments (Bell et al., 2006; Rego et al., 2009; Kliem and Shingfield, 2016). Around 70 to $95 \%$ of cis-9,trans-11 CLA found in milk is synthesized endogenously in the mammary gland from trans-11 18:1 originating from rumen biohydrogenation via the action of stearoyl-CoA desaturase 1 (Dewhurst et al., 2006). Further, approximately $20 \%$ of trans-11 18:1 received from the diet can be converted to cis-9,trans-11 CLA by humans (Kliem and Shingfield, 2016). The increases in trans-11 18:1 and cis-9,trans-11 CLA can be considered positive changes because cis-9,trans-11 CLA, in particular, has been shown to exhibit beneficial health effects, including anticarcinogenic activities (Dewhurst et al., 2006). The conjugated isomers of $18: 3 \mathrm{n}-3$ have similar beneficial properties to CLA, but more studies on their effect on human health are needed (Hennessy et al., 2011).

The proportion of cis-9 14:1 $\Delta^{9}$ desaturation products of 14:0 formed in the mammary gland or other tissues were highest in the MA diet, as observed earlier (Odongo et al., 2007). The increases in cis-11 16:1 and cis-13 18:1 in milk from cows fed MA indicated elongation of cis-9 14:1 in body tissues. Including myristic acid methyl ester in the diet clearly increased $\Delta^{9}$ de- saturation, with the strongest effect on desaturation of 16:0, which increased by up to $76 \%$ compared with CO. This resulted in higher amounts of MUFA and lower amounts of SFA in MA compared with CO. In parallel with a decrease in SFA, increases in cis MUFA and cis PUFA are desirable changes when milk fat is modified. As in the current study for RO, SO, and LO, inclusion of dietary plant oil supplements typically elevate amounts of cis MUFA in milk fat due to ruminal escape of cis-9 18:1 and 18:0, and endogenous $\Delta^{9}$ desaturation of 18:0 (Shingfield et al., 2013). By design, RO caused enrichment of cis-9 18:1 in milk fat, whereas SO promoted an increase in both cis-9 18:1 and 18:2n-6. Even high amounts of plant oils and oilseeds fed to lactating cows rarely result in more than $4 \%$ (wt/wt) total fatty acids of 18:2n-6 (Kliem and Shingfield, 2016).

Linseed oil supplements can be expected to promote increases in 18:3n-3 in milk fat up to $1 \%$ (wt/wt) fatty acids (Kliem and Shingfield, 2016). Increasing the amount of $18: 3 \mathrm{n}-3$ and other omega-3 fatty acids in milk is desirable because of their beneficial effects on cardiovascular health (Simopoulos, 2008). Surprisingly, proportions of 18:3n-3 in milk fat were similar in LO and CO despite higher intake of 18:3n-3 for LO. This is in line with an earlier experiment reporting even lower concentrations of 18:3n-3 in milk fat of grazing cows with linseed oil compared with the control (Rego et al., 2009). The discrepancies and the low transfer efficiency of 18:3n-3, and all-cis PUFA in general, into milk can be attributed to the magnitude of biohydrogenation in the rumen and the preferential incorporation of absorbed PUFA into plasma phospholipids and cholesterol esters instead of triacylglycerols, which is the main source of fatty acids for milk fat synthesis (Shingfield et al., 2013).

\section{Rumen Microbial Ecology}

Lipid supplements are known to have an inhibitory effect on rumen microorganisms, but qPCR analysis of ruminal samples collected in our study and reported in the complementary study of Tapio et al. (2016) did not show significant negative lipid effects on total quantities of ruminal bacteria, archaea, or ciliate protozoa. However, analysis of rumen microbiota using $16 \mathrm{~S}$ to $18 \mathrm{~S}$ rRNA gene sequencing data in the current study revealed changes in rumen microbial community abundances. These changes were related to the type of oil supplemented, with MA having the greatest effect of the compounds used here. Compared with CO, MA decreased abundances of specific fungi and ciliate protozoa, but its effect on the archaeal and bacterial taxa was more diverse. Regarding plant oils, archaea responded strongest to $\mathrm{SO}$, whereas bacteria 
were sensitive to LO. Among archaea, Methanobacterium alcaliphilum was more abundant for the diets supplemented with plant oils as compared with $\mathrm{CO}$ but did not tolerate MA. First isolated from sediments of low-salt lakes and studied in vitro (Worakit et al., 1986), Methanobacterium alcaliphilum requires sulfur or sulfide for its growth. Whether long-chain UFA affect the rumen ecosystem in ways that provide this archaea with necessary nutrients remains to be clarified. On the other hand, MA increased abundance of Methanimicrococcus blatticola and Methanosphaera ISO3-F5, which use methanol as a substrate. Methanol is produced when myristic acid methyl ester is de-esterified and would provide the required substrate for these archaea. In our study, changes in the abundance of Methanobrevibacter gottschalkii were significantly and positively associated with $\mathrm{CH}_{4}$ emissions (data not presented). Methanobrevibacter gottschalkii association with higher $\mathrm{CH}_{4}$ emissions has been suggested in Holstein cows (Zhou et al., 2011) and sheep (Shi et al., 2014) and is further supported by our data in Nordic Red cows. Contrary to the study in sheep, where animals selected for their naturally lower $\mathrm{CH}_{4}$ emissions showed elevated level of Methanosphaera spp. in their rumen (Shi et al., 2014), no significant correlation was observed between Methanosphaera spp. abundance and $\mathrm{CH}_{4}$ emissions in the current study (data not presented).

We did not explore rumen microbial community associations with phenotypic traits. Although diet significantly altered abundances of some ruminal taxa and phenotypic parameters, such as milk yield and composition, a lack of significant diet effect on rumen fermentation characteristics or nutrient digestibility in the first place would make microbiome-phenotype associations difficult to interpret.

\section{CONCLUSIONS}

Among the dietary lipid supplements, MA and RO lowered DMI, but only MA reduced milk yield. Treatments containing dietary lipid supplements had minor effects on rumen fermentation characteristics and nutrient digestion, other than an increase in ruminal ammonia-N concentration, which did not occur with LO, and improved $\mathrm{N}$ digestibility with MA. All lipid supplements lowered ruminal $\mathrm{CH}_{4}$ emission, with the largest decrease being for MA. Lower $\mathrm{CH}_{4}$ emission due to lipid supplements was entirely explained by decreases in DMI, the dilution effect on fermentable OM, and biohydrogenation of fatty acids in the rumen. All plant oil supplements improved milk fatty acid composition by reducing proportions of nutritionally undesirable de novo-synthesized 12:0, 14:0, 16:0, and total SFA and increasing cis MUFA. Feeding SO and LO resulted in the highest contents of PUFA and CLA in milk fat. The MA reduced de novo synthesis of medium-chain fatty acids and increased $\Delta^{9}$ desaturation without reducing total SFA. Lipid supplements altered diversity of rumen microbial communities and relative abundances of some less common taxa, but these changes did not affect ruminal fermentation or feed digestibility parameters. Further research is required to investigate ways to simultaneously mitigate $\mathrm{CH}_{4}$ emissions from dairy production and to improve milk quality. In particular, effects of dairy cow diet on milk fatty acid composition and bioactive lipids need to be studied, as well as putative detrimental, neutral, or positive health effects of dairy TFA on human health.

\section{ACKNOWLEDGMENTS}

The experiment was designed by late Kevin Shingfield, and his scientific expertise and inspiration were of utmost importance throughout the study. This experiment was financially supported by RuminOmics (project no. 289319 of EC 7th Framework Programme: Food, Agriculture, Fisheries and Biotechnology, European Commission, Brussels, Belgium). The authors express their appreciation to the staff in the metabolism unit of Natural Resources Institute Finland (Luke; formerly MTT Agrifood Research Finland) for technical support, care of experimental animals, and assistance in sample collection coordinated by Mari Talvisilta and in the laboratory for the chemical analysis of samples under the supervision of Taina Jalava. Thanks to Paula Lidauer for performing the ruminal cannulation surgery. The critical review by Pekka Huhtanen (Swedish University of Agricultural Sciences, Umeå, Sweden) and Phil Garnsworthy (Nottingham University, Loughborough, UK) is appreciated.

\section{REFERENCES}

Allen, M. S. 2000. Effects of diet on short-term regulation of feed intake by lactating dairy cows. J. Dairy Sci. 83:1598-1624.

Bayat, A. R., P. Kairenius, T. Stefanski, H. Leskinen, S. ComtetMarre, E. Forano, F. Chaucheyras-Durand, and K. J. Shingfield. 2015. Effect of camelina oil or live yeasts (Saccharomyces cerevisiae) on ruminal methane production, rumen fermentation, and milk fatty acid composition in lactating cows fed grass silage diets. J. Dairy Sci. 98:3166-3181.

Beauchemin, K. A., T. Coates, B. Farr, and S. M. McGinn. 2012. Technical note: Can the sulfur hexafluoride tracer gas technique be used to accurately measure enteric methane production from ruminally cannulated cattle? J. Anim. Sci. 90:2727-2732.

Beauchemin, K. A., and S. M. McGinn. 2006. Methane emissions from beef cattle: Effects of fumaric acid, essential oil, and canola oil. J. Anim. Sci. 84:1489-1496.

Bell, J. A., J. M. Griinari, and J. J. Kennelly. 2006. Effect of safflower oil, flaxseed oil, monensin, and vitamin E on concentration of conjugated linoleic acid in bovine milk fat. J. Dairy Sci. 89:733-748. 
Ben Salem, H., R. Krzeminski, A. Ferlay, and M. Doreau. 1993. Effect of lipid supply on in vivo digestion in cows: Comparison of hay and corn silage diets. Can. J. Anim. Sci. 73:547-557.

Benchaar, C., F. Hassanat, R. Martineau, and R. Gervais. 2015. Linseed oil supplementation to dairy cows fed diets based on red clover silage or corn silage: Effects on methane production, rumen fermentation, nutrient digestibility, $\mathrm{N}$ balance, and milk production. J. Dairy Sci. 98:7993-8008.

Benchaar, C., G. A. Romero-Pérez, P. Y. Chouinard, F. Hassanat, M. Eugène, H. V. Petit, and C. Côrtes. 2012. Supplementation of increasing amounts of linseed oil to dairy cows fed total mixed rations: effects on digestion, ruminal fermentation characteristics, protozoal populations, and milk fatty acid composition. J. Dairy Sci. 95:4578-4590.

Boadi, D. A., K. M. Wittenberg, and A. D. Kennedy. 2002. Validation of the sulphur hexafluoride $\left(\mathrm{SF}_{6}\right)$ tracer gas technique for measurement of methane and carbon dioxide production by cattle. Can. J. Anim. Sci. 82:125-131.

Bodirsky, B. L., S. Rolinski, A. Biewald, I. Weindl, A. Popp, and H. Lotze-Campen. 2015. Global food demand scenarios for the 21st century. PLoS One 10:e0139201.

Chelikani, P. K., J. A. Bell, and J. J. Kennelly. 2004. Effects of feeding or abomasal infusion of canola oil in Holstein cows 1. Nutrient digestion and milk composition. J. Dairy Res. 71:279-287.

Chilliard, Y., C. Martin, J. Rouel, and M. Doreau. 2009. Milk fatty acids in dairy cows fed whole crude linseed, extruded linseed, or linseed oil, and their relationship with methane output. J. Dairy Sci. 92:5199-5211.

Dewhurst, R. J., K. J. Shingfield, M. R. F. Lee, and N. D. Scollan 2006. Increasing the concentrations of beneficial polyunsaturated fatty acids in milk produced by dairy cows in high-forage systems. Anim. Feed Sci. Technol. 131:168-206.

Doreau, M., and Y. Chilliard. 1997. Digestion and metabolism of dietary fat in farm animals. Br. J. Nutr. 78(Suppl 1):S15-S35.

Doreau, M., and A. Ferlay. 2015. Linseed: A valuable feedstuff for ruminants. OCL 22:D611.

European Union. 1986. Council Directive 86/609/EEC on the approximation of laws, regulations and administrative provisions of the Member States regarding the protection of animals used for experimental and other scientific purposes. Off. J. L 358:1-28.

Gerber, P. J., H. Steinfeld, B. Henderson, A. Mottet, C. Opio, J. Dijkman, A. Falcucci, and G. Tempio. 2013. Tackling Climate Change Through Livestock - A Global Assessment of Emissions and Mitigation Opportunities. Food and Agriculture Organization of the United Nations (FAO), Rome, Italy.

Glasser, F., A. Ferlay, and Y. Chilliard. 2008. Oilseed lipid supplements and fatty acid composition of cow milk: A meta-analysis. J. Dairy Sci. 91:4687-4703.

Grainger, C., and K. A. Beauchemin. 2011. Can enteric methane emissions from ruminants be lowered without lowering their production? Anim. Feed Sci. Technol. 166-167:308-320.

Henderson, G., F. Cox, S. Ganesh, A. Jonker, W. YoungGlobal Rumen Census Collaborators, and P. H. Janssen. 2015. Rumen microbial community composition varies with diet and host, but a core microbiome is found across a wide geographical range. Sci. Rep. 5:14567.

Hennessy, A. A., R. P. Ross, R. Devery, and C. Stanton. 2011. The health promoting properties of the conjugated isomers of $\alpha$-linolenic acid. Lipids 46:105-119.

Hollmann, M., W. J. Powers, A. C. Fogiel, J. S. Liesman, N. M. Bello, and D. K. Beede. 2012. Enteric methane emissions and lactational performance of Holstein cows fed different concentrations of coconut oil. J. Dairy Sci. 95:2602-2615.

Hristov, A. N., C. Lee, T. Cassidy, M. Long, K. Heyler, B. Corl, and R. Forster. 2011. Effects of lauric and myristic acids on ruminal fermentation, production, and milk fatty acid composition in lactating dairy cows. J. Dairy Sci. 94:382-395.

Hristov, A. N., M. Vander Pol, M. Agle, S. Zaman, C. Schneider, P. Ndegwa, V. K. Vaddella, K. Johnson, K. J. Shingfield, and S. K. R. Karnati. 2009. Effect of lauric acid and coconut oil on ruminal fermentation, digestion, ammonia losses from manure, and milk fatty acid composition in lactating cows. J. Dairy Sci. 92:55615582 .

Huhtanen, P., S. Jaakkola, and J. Nousiainen. 2013. An overview of silage research in Finland: From ensiling innovation to advances in dairy cow feeding. Agric. Food Sci. 22:35-56.

Jenkins, T. C. 1993. Lipid metabolism in the rumen. J. Dairy Sci. $76: 3851-3863$.

Jenkins, T. C. 1998. Fatty acid composition of milk from Holstein cows fed oleamide or canola oil. J. Dairy Sci. 81:794-800.

Jordan, E., D. K. Lovett, F. J. Monahan, J. Callan, B. Flynn, and F. P. O'Mara. 2006. Effect of refined coconut oil or copra meal on methane output and on intake and performance of beef heifers. J. Anim. Sci. 84:162-170.

Kertz, A. F. 2010. Review: urea feeding to dairy cattle: A historical perspective and review. Prof. Anim. Sci. 26:257-272.

Kliem, K. E., and K. J. Shingfield. 2016. Manipulation of milk fatty acid composition in lactating cows: Opportunities and challenges. Eur. J. Lipid Sci. Technol. 118:1661-1683.

Knapp, J. R., G. L. Laur, P. A. Vadas, W. P. Weiss, and J. M. Tricarico. 2014. Invited review: Enteric methane in dairy cattle production: Quantifying the opportunities and impact of reducing emissions. J. Dairy Sci. 97:3231-3261.

Kriss, M. 1930. Quantitative relations of the dry matter of the food consumed, the heat production, the gaseous outgo, and the insensible loss in body weight of cattle. J. Agric. Res. 40:283-295.

Leskinen, H., S. Viitala, M. Mutikainen, P. Kairenius, I. Tapio, J. Taponen, L. Bernard, J. Vilkki, and K. J. Shingfield. 2016. Ruminal infusions of cobalt EDTA modify milk fatty acid composition via decreases in fatty acid desaturation and altered gene expression in the mammary gland of lactating cows. J. Nutr. 146:976-985.

Machmüller, A. 2006. Medium-chain fatty acids and their potential to reduce methanogenesis in domestic ruminants. Agric. Ecosyst. Environ. 112:107-114.

Machmüller, A., C. R. Soliva, and M. Kreuzer. 2003. Methane-suppressing effect of myristic acid in sheep as affected by dietary calcium and forage proportion. Br. J. Nutr. 90:529-540.

Martin, C., D. P. Morgavi, and M. Doreau. 2010. Methane mitigation in ruminants: From microbe to the farm scale. Animal 4:351-365.

MTT Agrifood Research Finland. 2006. Finnish feed tables and feeding recommendations: 2006. Accessed Jun. 13, 2015. http://www .luke.fi/rehutaulukot.

Odongo, N. E., M. M. Or-Rashid, E. Kebreab, J. France, and B. W. McBride. 2007. Effect of supplementing myristic acid in dairy cow rations on ruminal methanogenesis and fatty acid profile in milk. J. Dairy Sci. 90:1851-1858.

Oksanen, J., F. G. Blanchet, R. Kindt, P. Legendre, P. R. Minchin, R. B. O'Hara, G. L. Simpson, P. Solymos, M. H. H. Stevens, and H. Wagner. 2013. vegan: Community Ecology Package. R package version 2.0-10. Accessed Sep. 20, 2016. http://CRAN.R-project . org $/$ package $=$ vegan

Onetti, S. G., and R. R. Grummer. 2004. Response of lactating cows to three supplemental fat sources as affected by forage in the diet and stage of lactation: A meta-analysis of literature. Anim. Feed Sci. Technol. 115:65-82.

Rabiee, A. R., K. Breinhild, W. Scott, H. M. Golder, E. Block, and I. J. Lean. 2012. Effect of fat additions to diets of dairy cattle on milk production and components: a meta-analysis and metaregression. J. Dairy Sci. 95:3225-3247.

Rego, O. A., S. P. Alves, L. M. S. Antunes, H. J. D. Rosa, C. F. M. Alfaia, J. A. M. Prates, A. R. J. Cabrita, A. J. M. Fonseca, and R. J. B. Bessa. 2009. Rumen biohydrogenation-derived fatty acids in milk fat from grazing dairy cows supplemented with rapeseed, sunflower, or linseed oils. J. Dairy Sci. 92:4530-4540.

Roy, A., A. Ferlay, K. J. Shingfield, and Y. Chilliard. 2006. Examination of the persistency of milk fatty acid composition responses to plant oils in cows given different basal diets, with particular emphasis on trans-C18:1 fatty acids and isomers of conjugated linoleic acid. Anim. Sci. 82:479-492.

Shi, W., C. D. Moon, S. C. Leahy, D. W. Kang, J. Froula, S. Kittelmann, C. Fan, S. Deutsch, D. Gagic, H. Seedorf, W. J. Kelly, R. Atua, C. Sang, P. Soni, D. Li, C. S. Pinares-Patino, J. C. McEwan, 
P. H. Janssen, F. Chen, A. Visel, Z. Wang, G. T. Attwood, and E. M. Rubin. 2014. Methane yield phenotypes linked to differential gene expression in the sheep rumen microbiome. Genome Res. 24:1517-1525.

Shingfield, K. J., S. Ahvenjärvi, V. Toivonen, A. Ärölä, K. V. V. Nurmela, P. Huhtanen, and J. M. Griinari. 2003. Effect of dietary fish oil on biohydrogenation of fatty acids and milk fatty acid content in cows. Anim. Sci. 77:165-179.

Shingfield, K. J., S. Ahvenjärvi, V. Toivonen, A. Vanhatalo, P. Huhtanen, and J. M. Griinari. 2008. Effect of incremental levels of sunflower-seed oil in the diet on ruminal lipid metabolism in lactating cows. Br. J. Nutr. 99:971-983.

Shingfield, K. J., M. Bonnet, and N. D. Scollan. 2013. Recent developments in altering the fatty acid composition of ruminant-derived foods. Animal 7:132-162.

Shingfield, K. J., S. Jaakkola, and P. Huhtanen. 2002. Effect of forage conservation method, concentrate level and propylene glycol on diet digestibility, rumen fermentation, blood metabolite concentrations and nutrient utilization of dairy cows. Anim. Feed Sci. Technol. 97:1-21.

Simopoulos, A. P. 2008. The importance of the omega-6/omega-3 fatty acid ratio in cardiovascular disease and other chronic diseases. Exp. Biol. Med. (Maywood) 233:674-688.

Sjaunja, L. O., L. Baevre, L. Junkkarinen, J. Pedersen, and J. Setälä. 1990. A Nordic proposal for an energy corrected milk (ECM) formula. Page 156 in Proceedings of the 27th biennial session of the International Committee for Animal Recording (ICAR), Paris,
France. 2-6 July. J. A. M. van Arendonk, ed. Wageningen Academic Publishers, Wageningen, the Netherlands.

Tapio, I., K. J. Shingfield, N. Mckain, A. Bonin, D. Fischer, A. R. Bayat, J. Vilkki, P. Taberlet, T. J. Snelling, and R. J. Wallace. 2016. Oral samples as non-invasive proxies for assessing the composition of the rumen microbial community. PLoS One 11:e0151220.

Welter, K. C., C. M. Martins, A. S. V. de Palma, M. M. Martins, B. R. Dos Reis, B. L. U. Schmidt, and A. Saran Netto. 2016. Canola oil in lactating dairy cow diets reduces milk saturated fatty acids and improves its omega-3 and oleic fatty acid content. PLoS One 11:e0151876.

Worakit, S., D. R. Boone, R. A. Mah, M. E. Abdel-Samie, and M. M. El-Halwagi. 1986. Methanobacterium alcaliphilum sp. nov., an $\mathrm{H}_{2}$ utilizing methanogen that grows at high $\mathrm{pH}$ values. Int. J. Syst. Evol. Microbiol. 36:380-382.

Wu, Z., and J. Huber. 1994. Relationship between dietary fat supplementation and milk protein concentration in lactating cows: A review. Livest. Prod. Sci. 39:141-155.

Yu, Z., and M. Morrison. 2004. Improved extraction of PCR-quality community DNA from digesta and fecal samples. Biotechniques 36:808-812.

Zhou, M., Y. H. Chung, K. A. Beauchemin, L. Holtshausen, M. Oba, T. A. McAllister, and L. L. Guan. 2011. Relationship between rumen methanogens and methane production in dairy cows fed diets supplemented with a feed enzyme additive. J. Appl. Microbiol. 111:1148-1158. 